\title{
Extraction and Preconcentration of N-Tolyl-Sulfonyl-Phosphoramid- Saeure-Dichlorid as an Anti-Cancer Drug from Plants: A Pharmacognosy Study \\ Heidari $\mathbf{A}^{*}$
}

Faculty of Chemistry, California South University, USA

*Corresponding author: Heidari A, Faculty of Chemistry, California South University, 14731 Comet St. Irvine, CA 92604, USA, Tel: 1-775-410-4974; E-mail: scholar.researcher.scientist@gmail.com

Received date: March 26, 2016; Accepted date: April 01, 2016; Published date: April 05, 2016

Copyright: (c) 2016 Heidari A. This is an open-access article distributed under the terms of the Creative Commons Attribution License, which permits unrestricted use, distribution, and reproduction in any medium, provided the original author and source are credited.

\section{Editorial}

In the present short communication, a new and rapid Headspace Solvent Micro Extraction (HSME) method is utilized, for the extraction and preconcentration of the volatile and anti- cancer compounds such as N-Tolyl-Sulfonyl-Phosphoramid-Saeure-Dichlorid from plant samples into a microdrop [1-9]. The extraction occurred by suspending a microdrop of the solvent from the tip of a micro syringe to the headspace of the dried and powdered plants samples in a sealed vial for a preset extraction time [10-15]. Then, the microdrop was retracted back into the micro syringe and injected directly into a Gas Chromatography (GC) injection port (equipped with a Flame Ionization Detector (FID)). The identification of the volatile and anticancer compounds extracted by Headspace Solvent Micro Extraction (HSME) was confirmed according to their retention indices and mass spectra (EI, $150 \mathrm{eV}$ ) and quantitative analysis was performed by Gas Chromatography-Flame Ionization Detector (GC-FID). Parameters such as the sample temperature, micro syringe needle temperature, sample volume, extraction time and microdrop volume were studied and optimized in ten levels and finally, the method performance was evaluated.

On the other hand, N-Tolyl-Sulfonyl-Phosphoramid-SaeureDichlorid mustard and acrolein and its cyclic analogous such as Cyclophosphamide are shown anti-cancer activity [16-24]. N-TolylSulfonyl-Phosphoramid-Saeure-Dichlorid mustard and acrolein containing Amino Acid moiety have advantages in comparison to Cyclophosphamide because of releasing the non-toxic compounds in body after hydrolysis of the $\mathrm{P}-\mathrm{N}$ bond. This short communication will report a synthetic route for N-Tolyl-Sulfonyl-Phosphoramid-SaeureDichlorid mustard and acrolein containing Amino Acid. The Intermediate Phosphoramidate (I) obtained from reaction of appropriate Alcohol or Phenol with Phosphorus Oxychloride in the presence of Triethylamine in Dichloromethane (DCM) or Ether. The obtained Chlorophosphate Intermediate (I) was treated with Diethylamine or Bis-b-Chloroethyl Amin Hydrochloride in the presence of Triethylamine. Therefore, the obtained intermediate Phosphoramidate (II) was reacted with Phenyl Alanine Ethyl Ester Hydrochloride in the presence of Triethylamine to give the target molecules. The structure of products was designed using Attenuated Total Reflectance Fourier Transform Infrared Spectroscopy (ATRFTIR), FT-Raman, Mass, ${ }^{1} \mathrm{HNMR},{ }^{13} \mathrm{CNMR}$ and ${ }^{31} \mathrm{PNMR}$ spectroscopies and with data literature.

\section{References:}

1. Laudineia JM, Maria OM, Vanessa AR, Leonardo MR, Ariadna CS, et al (2016) Structure and histochemistry of medicinal species of Solanum. Revista Brasileira de Farmacognosia 26: 147-160.

2. Philip CS, Renée JG (2016) In Memoriam Nigel C Veitch, January 26th 1965-September 1st 2014. Phytochemistry 122: 301-302.

3. Pferschy-Wenzig EM, Bauer R (2015) The relevance of pharmacognosy in pharmacological research on herbal medicinal products. Epilepsy Behav 52: 344-362.

4. Roy Upton RH (2015) Traditional Herbal Medicine, Pharmacognosy, and Pharmacopoeial Standards: A Discussion at the Crossroads. In: Pulok K Mukherjee (eds) Evidence-Based Validation of Herbal Medicine. (1st edn), Elsevier, Boston.

5. Gilsane LVP, Cid ADMS (2015) Special issue for Brazilian Pharmacognosy Lecturers. Revista Brasileira de Farmacognosia. 25: 313.

6. Subhash CM, Vivekananda M, Anup KD (2015) Botanicals as a Screening Source of New Drugs: Past Success Stories and Present-Day Concerns. Essentials of Botanical Extraction. (1st edn), Academic Press, Boston.

7. Arnold JV, Luc P, Sandra A, Kanyanga Cimanga, Kahunu M, et al. (2015) The value of central-African traditional medicine for lead finding: Some case studies. J Ethnopharmacol 174: 607-617.

8. Karadeniz A, Alexie G, Greten HJ, Andersch K, Efferth T (2015) Cytotoxicity of medicinal plants of the West-Canadian Gwich in Native Americans towards sensitive and multidrug-resistant cancer cells. J Ethnopharmacol 168: 191-200.

9. Motz VA, Bowers CP, Kneubehl AR, Lendrum EC, Young LM, et al. (2015) Efficacy of the saponin component of Impatiens capensis Meerb. in preventing urushiol-induced contact dermatitis. J Ethnopharmacol 162: 163-167.

10. Tchouya GR, Souza A, Tchouankeu JC, Yala JF, Boukandou M, et al. (2015) Ethnopharmacological surveys and pharmacological studies of plants used in traditional medicine in the treatment of HIV/AIDS opportunistic diseases in Gabon. J Ethnopharmacol 162: 306-316.

11. Gireesh MA, Sandeep RP, Vinayak U, Pramod JH, Harsha VH (2015) Pharmacognostic evaluation of Achyranthes coynei: Leaf. Egyptian Journal of Basic and Applied Sciences 2: 25-31.

12. Ulf G, Sohaib M, Blazej S (2015) Cyclotides in the Violaceae. In: David JC (eds), Advances in Botanical Research. Academic Press, Boston

13. Bose KS, Sarma RH (1975) Delineation of the intimate details of the backbone conformation of pyridine nucleotide coenzymes in aqueous solution. Biochem Biophys Res Commun 66: 1173-1179.

14. Da Cheng Hao, Xiao-Jie Gu, Pei Gen Xiao (2015) Potentilla and Rubus medicinal plants: potential non-Camellia tea resources. Medicinal Plants. (1st edn), Woodhead Publishing, UK.

15. Ziaullah,Vasantha Rupasinghe HP (2015) Application of NMR Spectroscopy in Plant Polyphenols Associated with Human Health. In: Atta ur-Rahman, Iqbal CM (eds) Applications of NMR Spectroscopy. Bentham Science Publishers, United Arab Emirates. 
Citation: Heidari A (2016) Extraction and Preconcentration of N-Tolyl-Sulfonyl-Phosphoramid-Saeure-Dichlorid as an Anti-Cancer Drug from Plants: A Pharmacognosy Study. J Pharmacogn Nat Prod 2: e103. doi:10.4172/2472-0992.1000e103

Page 2 of 2

16. Debprasad C, Durbadal O, Supriya M, Debayan G (2015) Validation of Antiviral Potential of Herbal Ethnomedicine. In: Pulok K Mukherjee (eds) Evidence-Based Validation of Herbal Medicine. (1st edn), Elsevier, Boston.

17. Wangensteen H, Diallo D, Paulsen BS (2015) Medicinal plants from Mali: Chemistry and biology. J Ethnopharmacol 176: 429-437.

18. Assimos DG (2015) Re: Randomized and double-blinded clinical trial of the safety and calcium kidney stone dissolving efficacy of Lapis judaicus. J Urol 193: 897-898.

19. Krystyna SW, Alvaro MV (2015) Phytochemistry. International Symposium on Chromatography of Natural Products (ISCNP), Poland.
20. Satyajit DS (2015) In Essentials of Botanical Extraction. Academic Press, Boston.

21. Subhash CM, Vivekananda M, Anup Kumar Das (2015) In Essentials of Botanical Extraction. Academic Press, Boston.

22. Hans-Joachim Knölker (2015) The Alkaloids: Chemistry and Biology. Academic Press, Boston.

23. Karikari TK, Quansah E (2015) Neurogenomics: Challenges and opportunities for Ghana. Appl Transl Genom 5: 11-14.

24. Olim KK, Gulnara JA, Valeriy VP (2015) Some wild growing plants in traditional foods of Uzbekistan. Journal of Ethnic Foods. 2: 25-28. 